\title{
Pulpal Response to High Speed Cavity Preparation Using Water or Air Spray As Coolants
}

\author{
by \\ R. HOLLAND,* S. TAKAYAMA,* J. KOMATSU,* \\ M. RUSSO,* T. SAKAKI* and C. HOLLAND, Jr.*
}

\section{Introduction}

Several workers have related the pulpal response to cavity preparation[1,2,3,4], also relating it to water or air coolant[5,6,7]. A great divergence among the findings described by the above mentioned authors have led us to the realization of a work, in which we have concluded that the pulpal alterations are more closely related to cavity depth than to the coolant agent[8].

Nevertheless, the material employed as liner for the histopathological condition of the pulp at the time of the cavity preparation may influence the intensity of the tissue response. On the other hand, the authors have studied the pulpal response to cavity preparation in sound teeth and they have not used inert material as liner. Thus, it is thought that these variables must be studied, which theme in the object of this work.

\section{Material and Method}

There were used all the anterior teeth of 5 young adult dogs. Under general anaesthesia by sodium pentobarbital, a small portion of enamel was carefully removed of the middle portion of the vestibular surface. This remotion was performed with a round diamond bur at a low rotation. Twice a day during 3 days, the exposed dentin was submitted to alternate application of cold $\left(4^{\circ}\right.$ to $\left.6^{\circ} \mathrm{C}\right)$ and warm water $\left(55^{\circ}\right.$ to $60^{\circ} \mathrm{C}$ ). Forty-eight hours after the last stimulus, there were prepared simple cavities in the region already free of enamel. The cavities were prepared with diamond fissure bur mounted in air-turbine at a rotating speed of $250,000 \mathrm{rpm}$ under water or air cooling.

The cavities had their axial wall lined with paraffin or zinc oxide-eugenol before being sealed with silver amalgam.

The teeth were extracted 30 days later, fixed in $10 \%$ formalin and decalcified in formic acid-sodium citrate. After embedding in paraffin "in vacuo", the pieces were cut semiserially at $6 \mu$ and the sections were stained by hematoxylin and eosin.

\footnotetext{
* Therapeutic Department, Araçatuba School of Dentistry. Araçatuba (S.P.)-Brasil.
} 


\section{Results}

A. Cavities prepared under water cooling and lined with zinc oxide-eugenol.

A majority of the cavities in this group exhibited a remnant dentin layer at the floor of cavity with a thickness between $0.3-0.5 \mathrm{~mm}$. There was observed reactional dentin deposition with a reduced number of irregular canaliculi. The pulp was free from of inflammatory cell infiltration but the number of odontoblasts decreased. (Fig. 1).

\section{B. Cavities prepared under water cooling and lined with paraffin.}

In this group, the dentinal remnant layer was around $0.2-0.5$ milimiters thick. There was observed reactional dentin deposition with morphological characteristics similar to those mentioned in the anterior group. But all the specimens showed decrease in number of odontoblasts and some infiltration of lymphocytes, plasma cells and macrophages near to the site of exposition; occasionally some neutrophiles were also observed (Fig. 2).

\section{Cavities prepared under air cooling and lined with zinc oxide-eugenol.}

Under a remnant dentin layer $0.3-0.6 \mathrm{~mm}$ thick, the pulp did not present inflammatory reaction. The number of odontoblasts decreased and the reactional dentin was thicker, although similar to that of the anterior group (Fig. 3). Two specimens with dentinal remnant about $0.1 \mathrm{~mm}$ thick exhibited deposition of reactional dentin with very irregular canaliculi. The odontoblasts were very reduced in number and lymphocytes, plasma cells and macrophages were seldom observed in the pulp tissue subjacent to the cavity (Fig. 4).

\section{Gavities prepared under air cooling and lined with paraffin.}

The extension of dentin to the pulp after the preparation ranged between 0.3$0.4 \mathrm{~mm}$. The layer of reactional dentin was evidenced and it was thicker than that observed when water was used as coolant, but an intense infiltration of inflammatory cells was spread in larger areas (Fig. 5). Neutrophiles were more frequently observed.

It was also observed that when the dentinal remnant was $0.1 \mathrm{~mm}$ or less in thickness, the odontoblastic layer was degenerated and all the pulpal tissue was infiltrated by neutrophiles, presenting also numerous micro abscesses (Fig. 6).

\section{Discussion}

When the cavity preparation was done under air spray and the dentin floor was lined with paraffin, the tissue showed a more intense infiltration of inflammatory cells involving a much larger area than that observed when the teeth were not previously submitted to stimuli[8]. Furthermore, if the cavity was prepared leaving a layer only $0.1 \mathrm{~mm}$ thick protecting the pulp, this tissue was almost completely destroyed, thus differing from the findings of the authors above mentioned that have found signs of healing such as reactional dentin deposition and cell proliferation. If the cavity preparation was performed under water spray and paraffin was the liner employed, 
then the pulpal response was similar to that observed in teeth not stimulated[8].

In the group in which the zinc oxide-eugenol was applied to the cavity floor, the findings were different from those observed under paraffin. The absence of inflammatory cells infiltration was a rule and so, the method of cooling did not appear to make any difference in the reaction. This fact suggests an interference of the zinc oxide-eugenol on the effects consequent upon the operative trauma. By the 30th day, we have observed only a reduction in the number of odontoblasts and tubules in the reactional dentin and we have considered this fact as a sequel of the surgical trauma that has occurred. This observations is against to that which has been related about the employment of the zinc oxide-eugenol in different conditions. When it is used in direct contact with the dental pulp[9,10] or the periapical tissues[11,12], the zinc oxide-eugenol invariably evokes an inflammatory response. However, MASSLER[15] has called attention to the sedative effects of the zinc oxide-eugenol when it is applied in deep cavities. SILBERKWEIT and associates[14] have related, after histological study in rat incisors, that when the zinc oxide-eugenol was used as cavity liner, the injury was reduced and the healing process was accelerated.

In spite of that, we know that the inflammatory reaction produced by the zinc oxide-eugenol can be partially controlled by variations in its powder-liquid proportion: as the eugenol is decreased in the paste, the intensity of the inflammatory reaction is also decreased[15].

Moreover, according to SELTZER and Bender[16], the presence of a dentin layer between the pulp and the zinc oxide-eugenol appears to be necessary in order to prevent the occurrence of inflammatory response. Probably, the penetration of the eugenol through this layer toward the pulp would be very small. Thus a small proportion of eugenol to the powder would give to the paste the beneficial properties which were found by SILBERKWEIT and associates[14] and by us in this work.

LANGELAND[2] affirms that the alteration consequent upon the cavity preparation can persist in the pulp tissue in spite of the zinc oxide-eugenol. In our specimens whose cavities were lined with this material we have observed, as consequence upon the operative trauma, only a decrease in number of the odontoblasts and an irregular disposition of their cytoplasmic prolongations in the reactional dentin. By comparison of the results obtained in cavities lined with zinc oxide-eugenol or paraffin, we must conclude in one of the two ways: $a$ ) the eugenol is not so "inert" as LANGELAND[2] means or $b$ ) the paraffin is irritant to the dental pulp, at least when employed in the conditions of this work.

On the other hand, our observations and those of other authors[2,14] are not in agreement with those related by KONDO and MORI[17] according to which the zinc oxide-eugenol frequently destroys the pulp tissue because it has a strong action.

The results obtained in this work also permit us to call attention to the fact that if deep cavities are lined with substances irritant or inert to the dental pulp, there is the possibility of inflammatory process installation, with unexpected consequences. From the clinical view-point, it is impossible to predict when there will occur a more severe inflammatory reaction consequent upon the operative irritation over a pulp previously submitted to stimuli of unknown intensity. Therefore, it is very interesting to the clinician to know the frequency of occurrence of lesions related to the opera- 
tive injury. Furthermore, most of these lesions are subject to reversion, if cautions are not taken such as good cooling and employment of a liner that is not irritant to the pulp.

\section{Summary and Conclusions}

The anterior teeth of 5 young adult dogs, previously submitted to thermal stimuli during 3 days, had suffered cavities preparation with burs mounted in air turbine, under water or air cooling. The cavities were lined with zinc oxide-eugenol or paraffin and filled with silver amalgam. After 30 days, the pieces were removed and processed for microscopical analysis. The results obtained have permitted us to reach the following conclusions:

1) Teeth submitted to thermal stimuli in which cavities were prepared and lined with paraffin have showed a more intense pulpal inflammatory reaction, when the cavities were prepared under air spray than under water spray.

2) The cavities lining with zinc oxide-eugenol has produced, 30 days after the preparation, absence of pulpal inflammatory reaction independent of the method of cooling.

\section{References}

[1] Langeland, K.: Pulp reactions to high speed instrumentation, Norv. dent. J., 68: 137-139 (1958).

[2] LANGeland, K.: Histologic evaluation of pulp reactions to operative procedure, Oral Surg., 12: 1235-1248, (1959).

[3] Schuchard, A. S. and Watkins, E. C.: Pulp response at conventional and ultra-high speeds, using air coolant, J. Soc. Canad. Dent. Ass., 31: 391-395, (1963).

[4] Bouschor, C. F. and Matheus, J. L.: A four year clinical study of teeth restored after preparation with an air turbine hand piece with an air coolants, J. Prosth. Dent., 16: 306-309, (1966).

[5] Kramer, I. R. H.: Changes in the dental tissues due to cavity preparation using a turbine handpiece, Proc. roy. Soc. Med., 54: 239-247, (1961).

[6] Fajardo, O. P., Morgan, B. and Rovira, M. O. G.: Cambios de temperatura y repuesta pulpar producdos durante el corte de los tejidos duros del ciente, An. Fac. Odont. (Mont video), 2: 37-50, (1965).

[7] Dachi, S. F. and Stingers, R. W.: Pulp effects of water and air coolants used in high-speed cavity preparations, J. Amer. dent. Ass., 76: 95-98, (1968).

[8] Holland, R., Takayama, S. T. and Russo, M.: Avaliação histológica da reaço pulpar aopreparo de cavidades com turbina pneumática e refrigeração a água ou a ar, Rev. Ass. Paul. Cir. dent. 23: 89-95, (1969).

[9] Glass, R. L. and Zander, H. A.: Pulp healing, J. dent. Res., 28: 97-107, (1949).

[10] Mohammed, Y. R., Van Huysen, G. and Boyd, D. A.: Filling base materials and the unexposed and exposed tooth pulp, J. Prosth. Dent. 11: 503, (1961).

[11] Erausquin, J. and Muruzabal, M.: Root canal fillings with zinc eugenol cement in the rat molar, Oral Surg., 24: 547-558, (1967).

[12] Holland, R., Souza, V. and Milanezi, L. A.: Estudo morfológico da reação do côto pulpar e tecidos periapicais frente à alguns materiais empregados na obturação de canais radiculares, Ciência e Cultura, 20: 355, (1968).

[13] Massler, M.: Pulp protection and preservations, Year Book Publishers, Chicago, (1958).

[14] Silberkweit, M., Massler, M., Schour, I. and Weinman, J. P.: Effect of fillings materials on the pulp of rat incisors, J. dent. Res., 34: 854-869, (1955).

[15] Holland, R., Souza, V., Holland, Jr., C. and Nery, M. J.: Estudo histológico do comporta- 
mento do tecido celular subcutâneo do rato ao implante de alguns materiais obturadores de canal radicular. Influência da proporção pó-líquido, Rev. Assoc. Paul. Cir. Dent., 25: 101-110, (1970).

[16] Seltzer, S. and Bender, I. B.: The dental pulp, Lippincott Company, Philadelphia, (1965).

[17] Kondo, S. and Hori, Y.: Study on transaction of changes in pulp observed after cavity preparation, especially that of clinical findings, Bull. Tokyo Dent. Coll., 2: 1-12, (1961). 


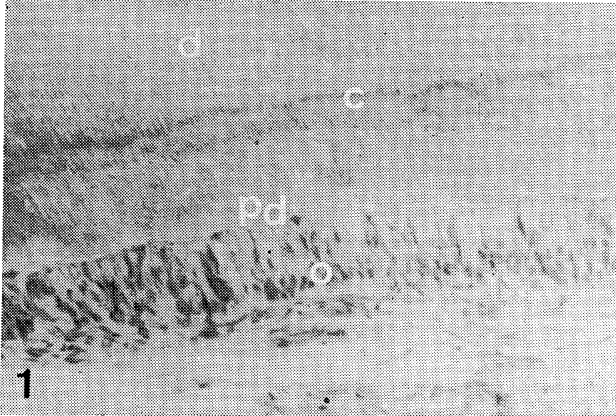

Fig. 1 Cavity prepared under water cooling and lined with zinc oxide-eugenol. The remnant dentine layer is $0.3 \mathrm{~mm}$ in thickness. D- dentin. C- calcium traumatic line. PD- predentin. C- odontoblastic layer. H. E. $260 \mathrm{x}$.

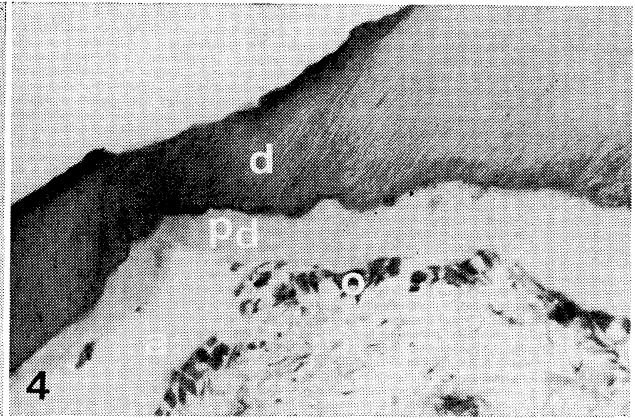

Fig. 4 Cavity prepared under air cooling and lined with zinc oxide-eugenol. The thickness of the remnant dentin layer is $0.1 \mathrm{~mm}$. D- dentin. PD- predentin. O- odontoblastic layer. A- artifact. H. E. 260 x.

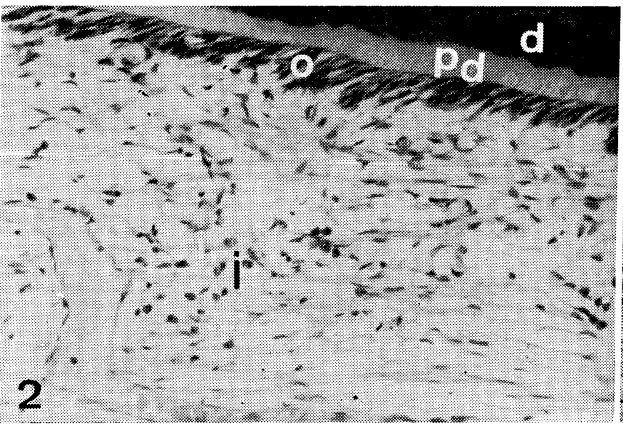

Fig. 2 Cavity prepared under water cooling and lined with paraffin. The remnant dentin layer is $0.4 \mathrm{~mm}$ thickness. Ddentin. PD- predentin. O- odontoblastic layer. I- infiltration of lymphocytes, plasma cells and macrophages. H. E. $260 \mathrm{x}$.

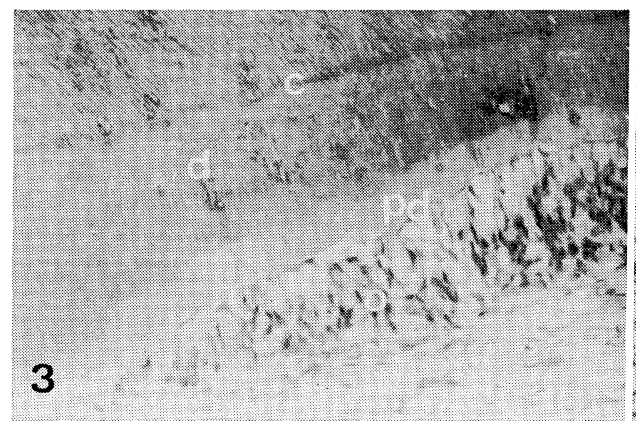

Fig. 3 Cavity prepared under air cooling and lined with zinc oxide-eugenol. The thickness of the remnant dentin layer is $0.4 \mathrm{~mm}$. C- calcium traumatic line. Ddentin. PD- predentin. O- odontoblastic layer. H. E. 260 x.

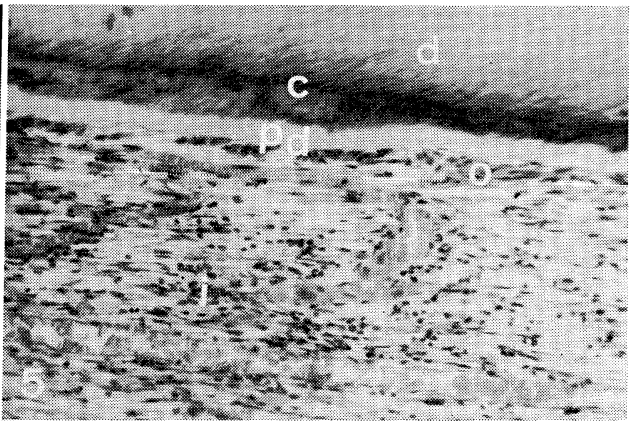

Fig. 5 Cavity prepared under air cooling and lined with paraffin. The thickness of the remnant dentin layer is $0.3 \mathrm{~mm}$. D- dentin. C- calcium traumatic line. PD- predentin. O- reduced odontoblastic layer. I- inflammatory cells. H. E. 260 x.

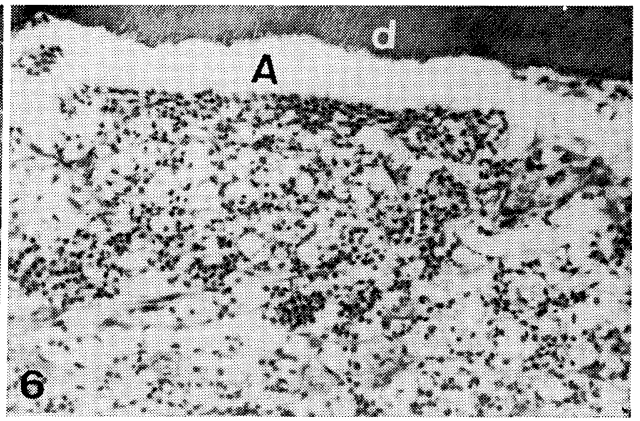

Fig. 6 Cavity prepared under air cooling and lined with paraffin. The thickness of the remnant dentin layer is $0.1 \mathrm{~mm}$. D- dentin. A- artifact. I- inflammatory cells (neutrophiles). H. E. $260 \mathrm{x}$. 